\title{
Surface roughness influences Candida albicans biofilm formation on denture materials
}

Wander José da Silva ${ }^{\mathrm{a}}$, Letícia Machado Gonçalves ${ }^{\mathrm{a}}$, Flávia Carvalho Viu ${ }^{\mathrm{a}}$, Cristiane Maria Brasil Leal ${ }^{\mathrm{a}}$, Célia Marisa Rizatti Barbosa ${ }^{a}$, Altair Antoninha Del Bel Cury ${ }^{a}$

\begin{abstract}
Objective: This study aimed to evaluate the influences of surface roughness (SR) of denture base and liner materials on Candida albicans biofilm formation.

Methods: Discs were fabricated using poly (methyl methacrylate) acrylic resin and poly(ethyl methacrylate) denture liner, according to manufacturers' instructions. Both acrylic resin and relined discs were finished or finished + polished and the SR was measured. Discs were saliva-coated, and C. albicans biofilms were developed on such surfaces for 48 hours. Biofilms were evaluated for cell counts, metabolic activity, and structural characteristics. Data were analyzed by one-way ANOVA and Tukey tests using a significance level of $5 \%$.

Results: Finished acrylic resin and denture liner discs had higher SR compared to finished + polished discs $(P<0.001)$. Finished + polished acrylic resin discs contained fewer cells compared to only finished discs $(P<0.001)$. No metabolic activity differences were seen between biofilms formed on both groups $(P>0.05)$. Bulky, thick and less rough biofilms were formed on only finished denture materials $(P<0.05)$. Confocal images reveal increased presence of black spaces for biofilms developed on finished + polished discs.

Conclusion: Reduced SR resulted in decreased C. albicans biofilm accumulation on both denture materials.
\end{abstract}

Key words: Acrylic resins; Biofilms; Candida albicans

\section{A rugosidade de superfície de materiais para prótese influencia a formação de biofilmes de Candida albicans}

\section{RESUMO}

Objetivo: Este estudo avaliou a influência da rugosidade de superfície (RS) de resina acrílica e materiais de reembasamento na formação de biofilmes de Candida albicans.

Métodos: Discos foram fabricados usando resina acrílica a base de poli(metil metacrilato) e reembasador a base de poli(etil metacrilato), seguindo as instruções dos fabricantes. Os discos tiveram a superfície acabada ou acabada + polida, e RS mensurada. Película de saliva foi formada na superfície dos discos, e biofilmes de C. albicans foram desenvolvidos por 48 horas. Biofilmes foram analisados para contagem, atividade metabólica e estrutura. Os dados foram analisados por ANOVA seguido do teste de Tukey a $5 \%$.

Resultados: Os discos apenas acabados apresentaram maior RS comparado aos acabados + polidos $(P<0,001)$. Discos de resina acabados + polidos formaram biofilmes com menos células quando comparados aos apenas acabados $(P<0,001)$. Não houve diferença para a atividade metabólica $(P>0,05)$. Biofilmes volumosos, espessos e menos rugosos foram formados nos discos acabados $(P<0,05)$. As imagens de confocal revelam o aumento da presença de espaços negros nos biofilmes em discos acabados + polidos.

Conclusão: Menores valores de RS resultaram em reduzido acúmulo de biofilme de C. albicans em ambos materiais para prótese.

Palavras-chave: Resinas acrílicas; Biofilmes; Candida albicans a Department of Prosthodontics and Periodontology, Piracicaba Dental School, University of Campinas, Piracicaba, SP, Brazil. 


\section{INTRODUCTION}

Candida albicans has been reported to play a major role in Candida-associated denture stomatitis (CADS) pathogenesis, and has been found on both poly(methyl methacrylate) (PMMA) acrylic resin and poly(ethyl methacrylate) (PEMA) liner materials [1-7]. For a successful colonization, $C$. albicans must first adhere to the denture surface [8] and the substratum characteristics, such as the surface roughness (SR), could influence this process.

Denture materials with rougher surfaces have been shown to exhibit higher yeast counts [7]. The higher porosity provides an increased chance of microbial retention and protection from the shear forces that arise during mechanical and chemical cleaning $[9,10]$. PMMA denture bases with a SR above $0.2 \mu \mathrm{m}$ have been shown to be readily colonized by $C$. albicans $[6,7]$. The physical characteristics of denture liners also make them susceptible to sorption and dimensional changes, which can result in porous surfaces that are easily colonized by fungal cells [5]. Although several studies have examined the role of SR in C. albicans adherence [2,3,7-12], the influence of SR on mature biofilms has been poorly investigated.

Studies on C. albicans adhesion and denture surface properties have primarily intended to characterize the surface properties of these materials and to assure standardization $[2$, $3,7-9,13,14]$. Few studies have used experimental conditions that simulate the clinical environment or studied conditions with varying SR. Therefore, in this study, SR differences were created by finishing and/or polishing denture materials. The aim of this study was to evaluate the influence of the SR of the denture-base material on C. albicans biofilm formation.

\section{METHODS}

This in vitro study was designed to be a random and blind study. Discs were fabricated using acrylic resin and permanent denture liner. After the disc surfaces were finished or finished + polished, the SR values were measured. Discs were saliva-coated and $C$. albicans biofilms were developed on the discs for up to 48 hours. Biofilms were analyzed for cell counts, metabolic activity, and structure. All assays were performed in triplicate in three independent experiments.

Discs $(10 \mathrm{~mm}$ diameter $\times 2 \mathrm{~mm}$ thickness $)$ were fabricated using PMMA acrylic resin (Lucitone 550; Dentsply, Rio de Janeiro, Brazil) and PEMA permanent denture liner (Tokuyama Rebase II; Tokuyama Dental Corp., Tokyo, Japan), according to the manufacturers' instructions. Acrylic resin discs were prepared using a metal mold and polymerized by water bath at $74^{\circ} \mathrm{C}$ for 9 hours. They were immersed in purified water at $37^{\circ} \mathrm{C}$ for 48 hours to release monomers. Additional $1-\mathrm{mm}$-thick resin discs $(10 \mathrm{~mm} \times 1 \mathrm{~mm})$ were fabricated for relining using a metal mold, as described elsewhere [3].

Both acrylic resin and relined discs were finished or finished + polished. For finishing, discs were ground using progressively smooth aluminum oxide papers $(320,400$ and 600 grit) in a horizontal polisher (model APL-4; Arotec, Sao Paulo, Brazil). For finishing + polishing, discs were additionally subjected to polishing with pumice and felt. The SR of each disc was measured to $0.01 \mu \mathrm{m}$ with a measurement length of $3.2 \mathrm{~mm}$ and $0.5 \mathrm{~mm} / \mathrm{s}$ using a profilometer (Surfcoder SE 1700; Kosaka Laboratory Ltd., Kosaka, Japan). Three readings were made for each disc, and a mean value was calculated. All discs were cleaned ultrasonically with sterile water for 20 minutes to remove any contaminants $[5,11]$.

C. albicans reference strain ATCC 90028 was cultured with agitation at $37^{\circ} \mathrm{C}$ for 20 hours in Yeast Nitrogen Base (YNB) broth (Difco Laboratories, Detroit, MI, USA) supplemented with $50 \mathrm{~mm}$ glucose. Cells were washed with phosphate-buffered saline (PBS, $\mathrm{pH}$ 7.2) and resuspended in YNB supplemented with $100 \mathrm{~mm}$ glucose. Cell densities were normalized optically to $10^{7}$ cells $/ \mathrm{mL}$ [11].

In order to mimic the oral cavity, the discs were coated with human salivary pellicle prior to biofilm development. Stimulated saliva was collected from two healthy volunteers after they had provided written formal consent, as required by the Local Ethical Committee for Research (protocol 082/2010). Saliva was collected in an ice-chilled polypropylene tube during masticatory stimulation with a flexible film and clarified by centrifugation $(10,000 \times g$ for $5 \mathrm{~min}$ at $4^{\circ} \mathrm{C}$ ). The supernatant was filter-sterilized and used immediately. Under aseptic conditions, each disc was placed inside a pre-sterilized 24-well culture plate and $2 \mathrm{~mL}$ of saliva was added to each well. The plate was incubated aerobically under agitation for $1 \mathrm{~h}$ at $35^{\circ} \mathrm{C}$ to form the salivary pellicle.

Saliva-coated discs were incubated under agitation at $37^{\circ} \mathrm{C}$ for 1.5 hours in 24 -well microtiter plates containing C. albicans in YNB media (adhesion phase). After adhesion and every 24 hours thereafter, the discs were washed with PBS, transferred to plates containing fresh media, and incubated for 48 hours. After 48 hours of biofilm development, the cell counts, metabolic activity, and structures of the biofilms were investigated.

To determine cell counts, discs were immersed in PBS and sonicated ( $7 \mathrm{~W}, 30$ seconds) to disrupt the biofilm structure. Suspensions were serially diluted in PBS and plated in triplicate onto Sabouraud Dextrose Agar (Difco Laboratories). Plates were incubated at $37^{\circ} \mathrm{C}$ for 24 hours. Yeast cells were counted as the number of cells per $\mathrm{mL}$. Metabolic activity was evaluated using the adapted XTT assay, as described elsewhere (15).

Biofilm structures were analyzed using confocal microscopy (Leica Microsystems CMS, Mannheim, GE). Biofilms were stained with SYTO-9 and propidium iodide (Molecular Probes, Eugene, OR, USA) and incubated in the dark at $37^{\circ} \mathrm{C}$ for 20 minutes. Images were captured at $1-\mu \mathrm{m}$ intervals along the $\mathrm{z}$-axis. At least five random optical fields were examined for each disc. COMSTAT software (16) was used to quantify structural parameters, including biovolume $\left(\mu \mathrm{m}^{3} / \mu \mathrm{m}^{2}\right)$, average thickness $(\mu \mathrm{m})$, and roughness coefficient $(\mu \mathrm{m})$. 
All data were analyzed using the SAS/LAB package (SAS Software, version 9.0; SAS Institute Inc., Cary, NC, USA) with the significance level set at 5\%. Differences in SR were evaluated by one-way ANOVA. Cell counts, metabolic activity, and structural parameters were assessed by one-way ANOVA followed by the Tukey test.

\section{RESULTS}

SR measurements for the processed acrylic resin and denture liner are shown in Table 1. Significant differences were observed between the SR measurements for the processed surfaces of both materials. Only finished acrylic resin and denture liner discs had higher SR compared to finished + polished discs $(P<0.001)$.

Table 1. Surface roughness of processed acrylic resin and denture liner discs.

\begin{tabular}{lcc}
\hline $\begin{array}{c}\text { Denture-base } \\
\text { material }\end{array}$ & Processing & $\begin{array}{c}\text { Surface roughness } \\
(\mu \mathrm{m})\end{array}$ \\
Acrylic resin & Finished & $0.29 \pm 0.03^{*}$ \\
& Finished + Polished & $0.15 \pm 0.05$ \\
Denture liner & Finished & $0.52 \pm 0.06^{*}$ \\
& Finished + Polished & $0.18 \pm 0.02$ \\
\hline
\end{tabular}

Data are the mean \pm standard deviation $(n=200)$

* Indicates significant differences between the processed surfaces (Tukey test, $P<0.05$ ).

Regarding the cell counts, it was observed that finished + polished acrylic resin discs contained fewer cells compared to only finished discs $(P<0.001$; Figure 1A). In contrast, differences in SR did not appear to affect the cell counts on denture liner discs $(P>0.05$; Figure 1A). No metabolic activity differences were seen between biofilms formed on finished and finished + polished discs $(P>0.05$; Figure $2 \mathrm{~B})$.

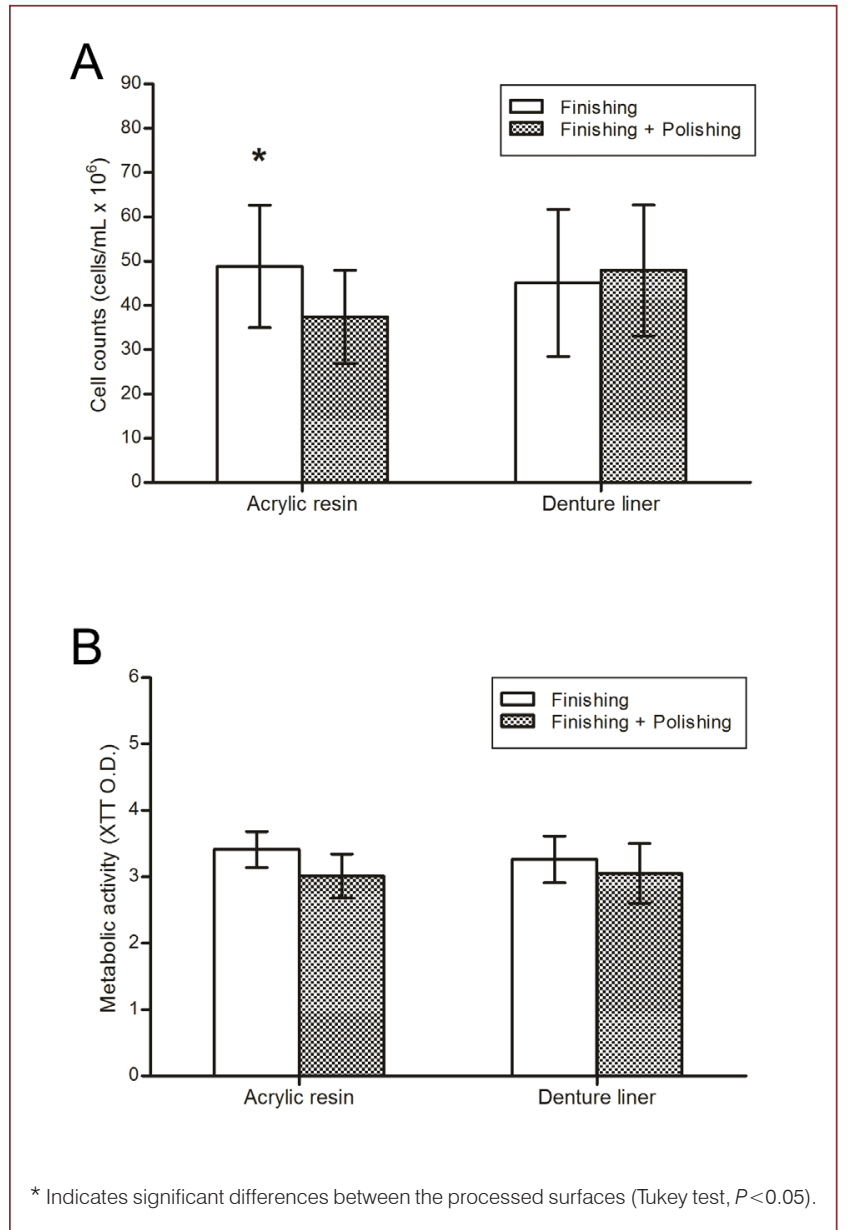

Figure 1. (A) Cell counts of $C$. albicans biofilms developed on finished or finished + polished denture materials. (B) Metabolic activity of C. albicans biofilms developed on finished or finished + polished denture materials

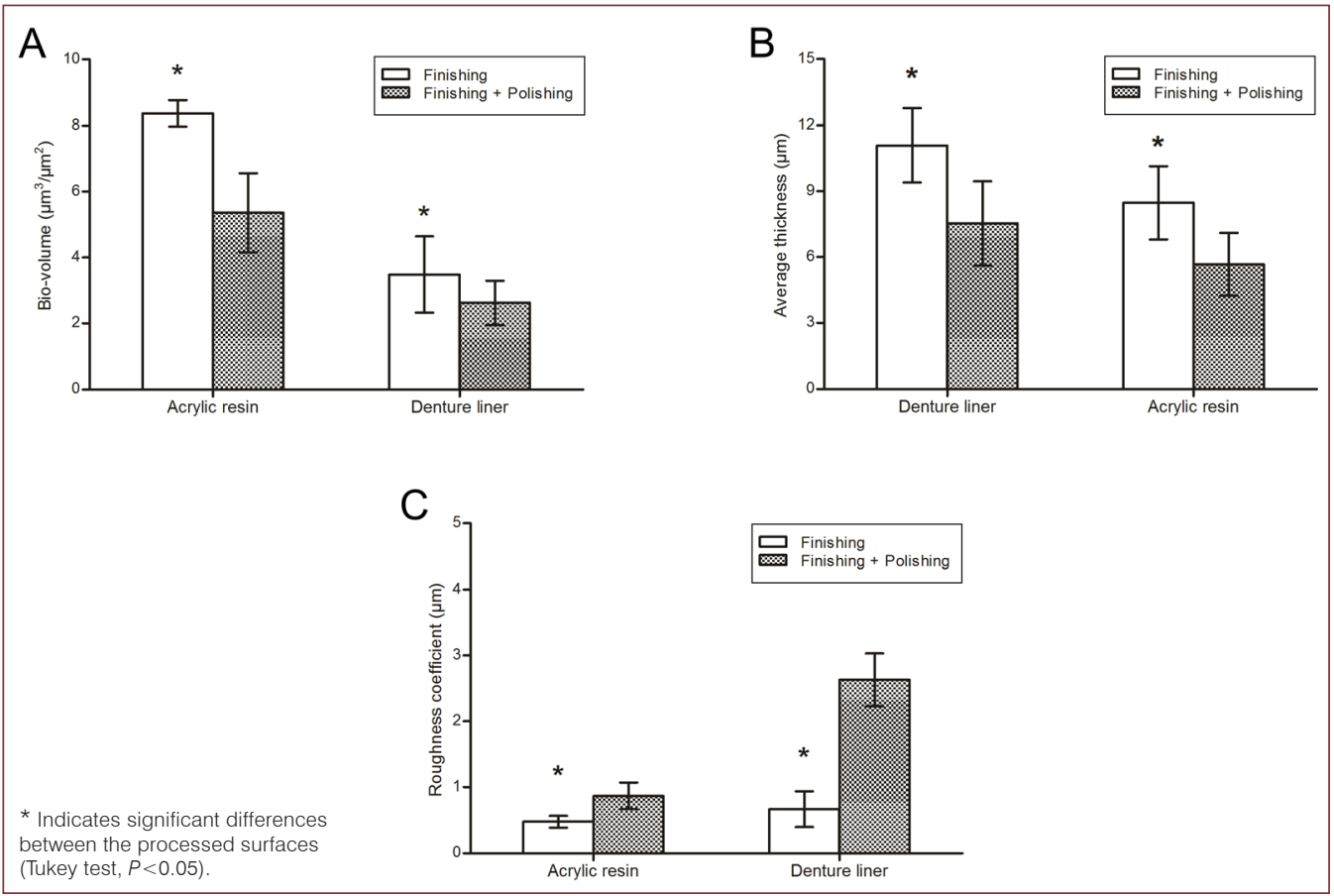

Figure 2.

(A) Biovolume $\left(\mu \mathrm{m}^{3} / \mu \mathrm{m}^{2}\right)$;

(B) average thickness $(\mu \mathrm{m})$, and $(\mathrm{C})$ roughness coefficient $(\mu \mathrm{m})$ of C. albicans biofilms developed on finished or finished + polished denture materials. 

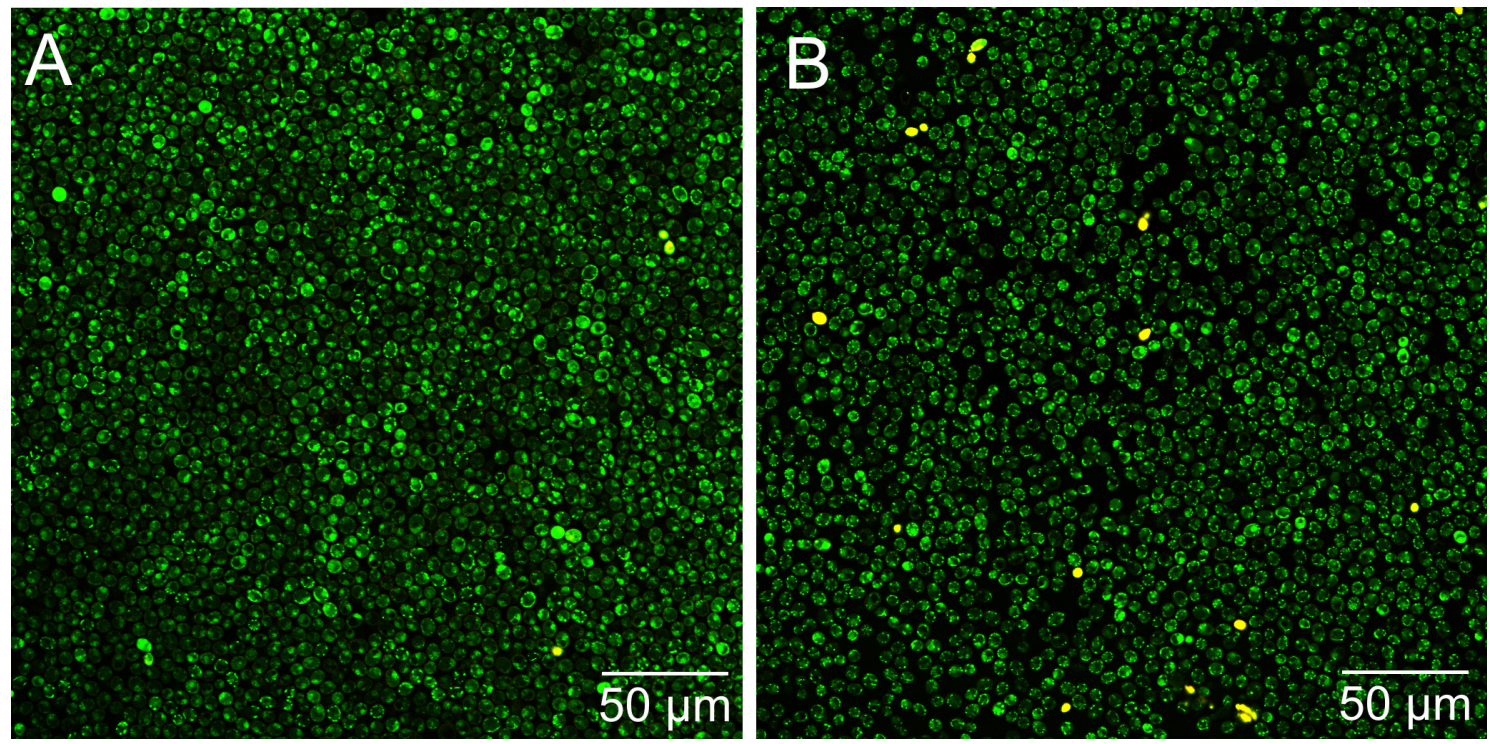

Figure 3. Confocal images of $C$. albicans biofilms developed on acrylic resin that was (A) finished or (B) finished + polished.

The type of disc surface processing (finished $v$ s. finished + polished) affected the biofilm structural parameters of biovolume, thickness and roughness coefficient, for both denture materials $(P<0.05$; Figure 2$)$. Rougher acrylic and liner discs surfaces (finished only) presented bulky, thick and less rough biofilms than the finished + polished surfaces $(P<0.05$; Figure 2A, 2B and 2C).

\section{DISCUSSION}

We assessed $C$. albicans biofilm formation on materials routinely used in prosthodontic procedures. The PMMA acrylic resin is the material of choice for denture fabrication due to its resistance, optical properties, aesthetics, and biocompatibility to oral tissues (11). However, for clinical situations in which patients present compromised alveolar bone support or after postoperative periods, the rigid PMMA base may damage the mucosa (4). In these circumstances, the use of denture liner material has been shown to improve denture retention and stability (5) and to distribute the masticatory forces that are transmitted to the underlying tissues (17).

Despite these favorable characteristics, C. albicans colonization has been directly associated with PMMA and liner materials. The SR of these materials have been shown to affect $C$. albicans colonization (2-5). Although several studies have examined the relationships between the SR of denture materials and microbial adhesion (2,3,7-12), to our knowledge, there were poor studies that evaluated the SR after modifying the materials by finishing and/or polishing (15).

The SR has been shown to be important for the adherence and entrapment of microorganisms on polymeric denture materials and for protecting microbes from shear forces (7). These materials should be as smooth as possible to prevent biofilm formation and oral mucosal inflammation, as well as to facilitate denture cleaning $(9,10)$. In contrast with other studies (2,3,7-10), we found that the SR did not affect the adhesion of $C$. albicans to either denture-base material. Previous studies have reported a threshold roughness value of $0.2 \mu \mathrm{m}$, below which the SR does not affect microbial adhesion $(6,7)$. In our study, the finished + polished PMMA acrylic resin and PEMA denture liner materials had SR values of 0.15 and $0.18 \mu \mathrm{m}$, respectively, and promoted yeast adhesion.

Whereas most studies have measured the SR to characterize the material surface and ensure the standardization of the finishing procedures, in this study, we evaluated the effects of the finishing and/or polishing on adhesion under conditions that simulated the clinical environment of saliva-coated surfaces. The presence of the salivary pellicle may have masked the inhibition of adhesion seen with a low SR.

In contrast, for mature biofilms, the yeast cell counts were higher on unpolished PMMA acrylic resin compared to the polished resin. Because a higher SR means a greater specific surface area and more available surface sites for colonization $(7,10)$, it follows that the SR is directly related to the amount of microorganisms deposited on the surface. It is possible that irregularities present within finishedonly surfaces entrapped the C. albicans cells and allowed the formation of bulky and thick biofilms, as observed in confocal images. To address this possibility, additional experiments should be performed in the presence or absence of salivary pellicle with discs that have a wider range of roughness values.

\section{CONCLUSIONS}

Regardless of the limitations of this study, it can be conclude that the SR of denture-base materials influenced the $C$. albicans biofilms colonization. Discs with lower SR 
values had reduced $C$. albicans biofilm accumulation on both denture materials.

\section{ACKNOWLEDGMENTS}

The authors thank FAPESP for their financial support (2010/02091-5).

\section{REFERENCES}

1. Emami E, Taraf H, de Grandmont P, Gauthier G, de Koninck L, Lamarche C, de Souza RF. The association of denture stomatitis and partial removable dental prostheses: a systematic review. Int J Prosthodont 2012;25: 113-9.

2. Nevzatoglu EU, Ozcan M, Kulak-Ozkan Y, Kadir T. Adherence of Candida albicans to denture base acrylics and silicone-based resilient liner materials with different surface finishes. Clin Oral Investig 2007:11: 231-6. https://doi.org/10.1007/s00784-007-0106-3

3. Pereira-Cenci T, Cury AA, Cenci MS, Rodrigues-Garcia RC. In vitro Candida colonization on acrylic resins and denture liners: influence of surface free energy, roughness, saliva, and adhering bacteria. Int J Prosthodont 2007; 20:308-10

4. Kang SH, Lee HJ, Hong SH, Kim KH, Kwon TY. Influence of surface characteristics on the adhesion of Candida albicans to various denture lining materials. Acta Odontol Scand 2012. https://doi.org/10.3109/ 00016357.2012 .671360

5. Goncalves LM, Del Bel Cury AA, Sartoratto A, Garcia Rehder VL, Silva WJ. Effects of undecylenic acid released from denture liner on Candida biofilms. J Dent Res 2012;91:985-9. https://doi.org/10.1177/0022034512458689

6. Quirynen M, Marechal M, Busscher $\mathrm{HJ}$, Weerkamp $\mathrm{AH}$, Darius $\mathrm{PL}$ van Steenberghe D. The influence of surface free energy and surface roughness on early plaque formation. An in vivo study in man. J Clin Periodontol 1990;17:138-44. https://doi.org/10.1111/j.1600-051X.1990. tb01077.x

7. Radford DR, Challacombe SJ, Walter JD. Denture plaque and adherence of Candida albicans to denture-base materials in vivo and in vitro. Crit Rev Oral Biol Med 1999;10:99-116. https://doi.org/10.1177/1045441199 0100010501

8. Hahnel S, Henrich A, Rosentritt M, Handel G, Burgers R. Influence of artificial ageing on surface properties and Streptococcus mutans adhesion to dental composite materials. J Mater Sci Mater Med 2010;21:823-33. https://doi.org/10.1007/s10856-009-3894-y

9. Tari BF, Nalbant D, Dogruman AI F, Kustimur S. Surface roughness and adherence of Candida albicans on soft lining materials as influenced by accelerated aging. J Contemp Dent Pract 2007;8:18-25

10. Radford DR, Sweet SP, Challacombe SJ, Walter JD. Adherence of Candida albicans to denture-base materials with different surface finishes. J Dent 1998:26:577-83. https://doi.org/10.1016/S0300-5712(97)00034-1

11. da Silva WJ, Seneviratne J, Samaranayake LP, Del Bel Cury AA. Bioactivity and architecture of Candida albicans biofilms developed on poly (methyl methacrylate) resin surface. J Biomed Mater Res B Appl Biomater 2010; 94:149-56. https://doi.org/10.1002/jbm.b.31635

12. Teughels W, Van Assche N, Sliepen I, Quirynen M. Effect of materia characteristics and/or surface topography on biofilm development. Clin Oral Implants Res 2006;17 Suppl 2:68-81. https://doi.org/10.1111/j.16000501.2006.01353.x

13. Nikawa H, Nishimura H, Makihira S, Hamada T, Sadamori S, Samaranayake LP. Effect of serum concentration on Candida biofilm formation on acrylic surfaces. Mycoses 2000;43:139-43. https://doi.org/10.1046/j.14390507.2000.00564.X

14. Minagi S, Miyake $Y$, Inagaki $K$, Tsuru H, Suginaka H. Hydrophobic interaction in Candida albicans and Candida tropicalis adherence to various denture base resin materials. Infect Immun 1985;47:11-4.

15. da Silva WJ, Seneviratne J, Parahitiyawa N, Rosa EA, Samaranayake LP, Del Bel Cury AA. Improvement of XTT assay performance for studies involving Candida albicans biofilms. Braz Dent J 2008:19:364-9. https:/ doi.org/10.1590/S0103-64402008000400014

16. Heydorn A, Nielsen AT, Hentzer M, Sternberg C, Givskov M, Ersboll BK, Molin S. Quantification of biofilm structures by the novel computer program COMSTAT. Microbiology 2000;146(Pt 10):2395-407. https://doi. org/10.1099/00221287-146-10-2395

17. Vieira AP, Senna PM, Silva WJ, Del Bel Cury AA. Long-term efficacy of denture cleansers in preventing Candida spp. biofilm recolonization on liner surface. Braz Oral Res 2010;24:342-8. https://doi.org/10.1590/S180683242010000300014 